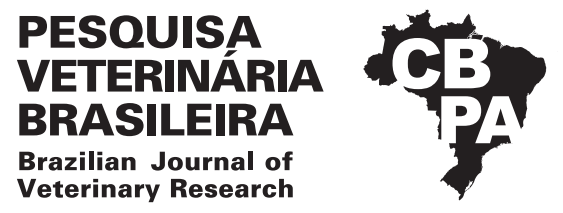

Pesq. Vet. Bras. 39(8):649-654, August 2019 DOI: 10.1590/1678-5150-PVB-6083

Original Article

ISSN 0100-736X (Print)

ISSN 1678-5150 (Online)

\title{
Canine monocytic ehrlichiosis in Buenos Aires, Argentina: comparison of serological and molecular assays ${ }^{1}$
}

\author{
Paula L. Martin ${ }^{3}$ (D), María N. De Salvo², Gabriel L. Cicuttin ${ }^{2 *}$ and María S. Arauz
}

\begin{abstract}
Martin P.L., De Salvo M.N., Cicuttin G.L. \& Arauz M.S. 2019. Canine monocytic ehrlichiosis in Buenos Aires, Argentina: comparison of serological and molecular assays. Pesquisa Veterinária Brasileira 39(8):649-654. Laboratorio de Zoonosis Bacterianas y Parasitarias Transmitidas por Vectores, Instituto de Zoonosis Luis Pasteur, Av. Díaz Velez 4821, CABA, CP C1405DCD, Argentina. E-mail: gcicuttin@gmail.com

Canine monocytic ehrlichiosis (CME) is an infectious disease caused by the bacterium Ehrlichia canis and transmitted by Rhipicephalus sanguineus sensu lato, a tick with worldwide distribution. When not diagnosed and treated early, disease can be severe. Currently, the disease is confirmed by serological or molecular assays. The objective of this study was to compare a serological assay based on immunochromatography (SPEED ${ }^{\circledR}$ EHRLI immunochromatographic test; BVT, France) and a molecular assay (a screening PCR followed by a nested PCR specific for E. canis) for the diagnosis of E. canis in suspected dogs from Buenos Aires city and southern Greater Buenos Aires, Argentina. Blood samples from 20 clinically healthy dogs (Control Group) and from 80 sick dogs suspected of having CME (Groups 1 to 4) were tested in parallel. Neither the immunochromatographic test nor the PCR assay was able to detect the presence of E. canis in the Control Group. In the group which had been previously tested by serology, the agreement between the tests was low (kappa: 0.200), whereas in the group which had been previously tested by PCR, the concordance between the tests was adequate (kappa: 0.650). The concordance between the tests evaluated in the total population studied was moderate (kappa: 0.496 ). The results of our study suggest that the use of rapid serological tests as a first approach, together with subsequent confirmation by PCR, will improve the diagnosis of CME.
\end{abstract}

INDEX TERMS: Canine, monocytic ehrlichiosis, Buenos Aires, Argentina, serology, molecular assay, dogs, diagnosis, ehrlichiosis, PCR, bacterioses.

RESUMO.- [Ehrlichiose monocítica canina em Buenos Aires: comparação de testes serológicos e moleculares.] A ehrlichiose monocítica canina (CME) é uma doença infecciosa transmitida pelo carrapato Rhipicephalus sanguineus sensu lato com distribuição mundial causada por Ehrlichia canis, que pode produzir uma doença grave se não foi diagnosticada e tratada precocemente. A confirmação da doença é feita diretamente pela deteç̧ão do DNA fazendo a reação em cadeia da polimerase (PCR) ou indiretamente por métodos sorológicos.

\footnotetext{
${ }^{1}$ Received on March 12, 2019.

Accepted for publication on April 7, 2019.

${ }^{2}$ Laboratorio de Zoonosis Bacterianas y Parasitarias Transmitidas por Vectores, Instituto de Zoonosis Luis Pasteur, Av. Díaz Velez 4821, Ciudad Autónoma de Buenos Aires, CP C1405DCD, Argentina. *Corresponding author: gcicuttin@gmail.com

${ }^{3}$ Servicio Central, Laboratorio del Hospital Escuela, Facultad de Ciencias Veterinarias, Universidad Nacional de La Plata (UNLP), Av. 60 y 118, CC 296, La Plata, CP 1900, Buenos Aires.
}

O objetivo deste estudo foi comparar o método sorológico baseado na imunocromatografia e a técnica de PCR para o diagnóstico de E. canis em cães suspeitos da Cidade de Buenos Aires e da região sul da Grande Buenos Aires. As amostras de sangue de 20 cães clinicamente saudáveis (Grupo Controle) e de 80 cães com suspeita clínica de CME (Grupo 1-4) foram avaliadas em paralelo. 0 diagnóstico serológico foi feito pelo teste imunocromatográfico SPEED ${ }^{\circledR}$ EHRLI (BVT, França). Para a detecção molecular, foi utilizada uma PCR de triagem para amplificar um fragmento de $345 \mathrm{pb}$ do gene que codifica a subunidade 16S do rRNA da família Anaplasmataceae. As amostras positivas depois foram processadas pela PCR aninhada específica para E. canis. No Grupo Controle, a presença de E. canis não foi detectada por PCR ou anticorpos específicos com o teste imunocromatográfico. No grupo em que a sorologia foi solicitada inicialmente (1 e 2), a concordância entre os testes foi baixo (kappa: 0,200) enquanto que no grupo onde o teste inicialmente solicitado foi a PCR, a concordância 
entre os testes era adequado (kappa: 0,650). A concordância entre os testes avaliados na população total estudada foi moderada (kappa: 0,496). Em conclusão, os resultados do nosso estudo sugerem que o uso de testes serológicos rápidos inicialmente, juntamente com a confirmação subsequente por PCR, permitirá melhorar o diagnóstico de CME.

TERMOS DE INDEXAÇÃO: Ehrlichiose monocítica, caninos, Buenos Aires, teste serológico, teste molecular, cães, diagnóstico, ehrlichiose, PCR, bacterioses.

\section{INTRODUCTION}

Canine monocytic ehrlichiosis (CME) is a tick-borne disease caused by Ehrlichia canis, an obligate intracellular bacterium of the family Anaplasmataceae. This bacterium is mainly transmitted by the tick Rhipicephalus sanguineus sensu lato (Dumler et al. 2001, Bremer et al. 2005). In dogs, the clinical presentation of CME can range from mild to severe depending on the immune status of the host, virulence of the strain and co-infection with other microorganisms (Klag et al. 1991, Unver et al. 2009, Rotondano et al. 2015). The course of CME can be divided into three phases: acute, subclinical and chronic. The acute phase is characterized by high fever, depression, lethargy, anorexia, lymphadenomegaly, splenomegaly, hemorrhagic tendencies and ophthalmological signs (Neer et al. 2002, Leiva et al. 2005, Harrus et al. 2012). Untreated dogs and those treated inappropriately may recover clinically but then enter the subclinical phase. In this phase, dogs show no clinical signs but may remain persistent carriers of E. canis. In the chronic phase, signs are more severe and infected dogs may be less responsive to therapy (Neer et al. 2002, Harrus et al. 2012). Therefore, early and accurate diagnosis of suspected cases in dogs is essential to alter the course of this disease (Neer et al. 2002).

Currently, diagnosis of CME includes direct (e.g. blood smears and PCR) and indirect (serology) methods (Harrus \& Waner 2011). The evaluation of blood smears has low sensitivity and specificity (Mylonakis et al. 2003, Ramos et al. 2009, Harrus et al. 2012). Although this method may be optimized by the examination of multiple buffy coat smears, the presence of platelets, lymphocytic azurophilic granules, and phagocytosed nuclear material may all be confused with ehrlichial inclusions (Harrus \& Waner 2011). In contrast, the PCR assay is a sensitive method to detect E. canis DNA. Thus, several assays based on different target genes, such as $16 \mathrm{~S}$ rRNA, p28, p30, $d s b$, VirB9, and groESL, have been published (Stich et al. 2002, Labruna et al. 2007, Baneth et al. 2009, Cicuttin et al. 2016). Both conventional and real time PCR have the advantage over serology that they can detect active infection in a single sample (Harrus \& Waner 2011, Maggi et al. 2014). However, in animals with subclinical infection, in which E. canis persists in the bone marrow or spleen but is below the limit of PCR detection in peripheral blood, these assays could give negative results (Harrus et al. 1998, Otranto et al. 2010). Regarding indirect methods, the indirect immunofluorescence antibody assay is considered the 'gold standard' for detection and titration of E. canis antibodies (Waner et al. 2001, Harrus et al. 2002). However, this assay usually presents cross-reactivity between $E$. canis and other ehrlichiae and to confirm recent infection, it should be repeated in 2-3 weeks to demonstrate seroconversion (i.e. a four-fold change in the patient's antibody titer between acute and convalescent serum samples). There are also several commercial serological assays, such as rMAP2 ELISA, InDx Canine Multiassay Dip-S-Ticks (PanBio, InDx), Snap Combo, Snap3Dx (IDEXX Laboratories), Snap 4Dx (IDEXX Laboratories), and SPEED ${ }^{\circledR}$ EHRLI (BVT, France), which have been designed for in-clinic use. However, serological assays are not appropriate to confirm active infection because antibodies can persist for variable intervals after a pathogen is eliminated (Harrus et al. 1998). For a suitable diagnosis of CME and to detect acutely infected dogs before seroconversion and/or sub clinically infected dogs with blood negative PCR, it is thus recommended to use serology in conjunction with molecular detection methods (Çetinkaya et al. 2016).

In Argentina, E. canis has only been confirmed in dogs with compatible signs of EMC from Buenos Aires (Eiras et al. 2013, Cicuttin et al. 2016) and R. sanguineus ticks from Formosa and Buenos Aires (Cicuttin et al. 2015, Cicuttin et al. 2017). Using molecular assays, Eiras et al. (2013) have detected E. canis in 6/86 (7.0\%) dogs with suspected blood smear evidence and/or thrombocytopenia from southern Greater Buenos Aires. Cicuttin et al. (2016) in samples of canines with symptoms compatible with EMC of the Metropolitan Area of Buenos Aires described a prevalence of 6.7\% (15/223) to $E$. canis. On the other hand, in clinical healthy dogs from Buenos Aires, San Luis, Córdoba and Santa Fe, only the presence of Anaplasma platys DNA, but not E. canis, was demonstrated (Cicuttin et al. 2011, 2014a, 2014b, 2017a, Mascarelli et al. 2016). Serological studies published in our country are scarce. Mera y Sierra \& Neira (2014) found that $46.6 \%$ of canines from Mendoza with symptoms compatible were seropositive for $E$. canis with Speed-Ehrli serological assay.

Since comparison between these direct and indirect assays may provide valuable information for the diagnosis of CME in clinical practice, the objective of this study was to compare a serological assay based on immunochromatography with a molecular assay for diagnosis of CME by using samples from healthy dogs and dogs suspected of being infected with CME from Buenos Aires, Argentina.

\section{MATERIALS AND METHODS}

Sample collection. Whole blood samples with EDTA anticoagulant received for the diagnosis of CME were kindly provided by two diagnostic centers: "Laboratorio Diagnóstico Veterinario Sur", Quilmes, southern Buenos Aires (a center where dogs are diagnosed by means of a serological assay), and "Instituto de Zoonosis Luis Pasteur", Buenos Aires, Argentina (a center where dogs are diagnosed by means of a molecular assay). Only samples from animals with presumptive clinical diagnosis of CME were selected. In all cases, the samples were stored at $-20^{\circ} \mathrm{C}$ until their processing. In addition, whole blood samples with EDTA from clinically healthy dogs from the same locations were included to establish background exposure or infection (Control Group). The samples from sick dogs were divided into four groups taking into account the result of the serology or PCR assay previously performed at the diagnostic center: Group 1, which consisted of 20 samples in which the serological SPEED ${ }^{\circledR}$ EHRLI assay had been negative for Ehrlichia canis; Group 2, which consisted of 20 samples in which the serological SPEED ${ }^{\circledR}$ EHRLI assay had been positive for E. canis; Group 3, which consisted of 20 samples in which the PCR assay (screening PCR targeted to the 16 S ribosomal RNA and nested PCR targeted to a specific fragment 
of the 16S rRNA gene from E. canis assays) had been negative for E. canis; and Group 4, which consisted of 20 samples in which the PCR assay had been positive for E. canis.

Serological assay. The serological diagnosis of the samples obtained from the two diagnostic centers was also performed by the SPEED ${ }^{\circledR}$ EHRLI assay. This commercial assay is based on the detection of anti-E. canis antibodies by using an immunochromatographic membrane. The cut-off value from which the assay detects specific antibodies is not specified by the manufacturer. The sensitivity and specificity of the assay is $87 \%$ and $95 \%$ respectively (Martin 2004).

Whole blood was used according to the manufacturer's instructions. This method was used for the detection of anti-E. canis antibodies in the 60 samples corresponding to Groups 3 and 4 and the controls.

Molecular assay. For the molecular assays, DNA was extracted from $200 \mu \mathrm{L}$ of whole blood samples with EDTA anticoagulant, using the High Pure PCR Template Preparation Kit (Roche, Mannheim, Germany), according to the manufacturer's instructions. Initial screening for the family Anaplasmataceae was performed with a screening PCR assay targeted to the 16 S ribosomal RNA (16S rRNA) gene (Table 1). Reactions were performed in a final volume of $25 \mu \mathrm{L}$, containing $12.5 \mathrm{pmol}$ of each primer. The thermocycling conditions for the reactions were $95^{\circ} \mathrm{C}$ for $5 \mathrm{~min}$, followed by 34 cycles at $95^{\circ} \mathrm{C}$ for 30 seconds, with annealing at $55^{\circ} \mathrm{C}$ for $30 \mathrm{~s}$, and extension at $72^{\circ} \mathrm{C}$ for 90s; a final extension step at $72^{\circ} \mathrm{C}$ for $5 \mathrm{~min}$ was used. In each PCR reaction, an endogenous control was included to amplify a $289 \mathrm{bp}$ region of exon III of the beta-actin gene to evaluate the presence of inhibitors. Anaplasma centrale was used as a positive control and nuclease-free water was used as a negative control.

Positive DNAs by screening PCR assay were then analyzed by nested PCR assay to amplify a specific fragment of the $16 \mathrm{~S}$ rRNA gene from E. canis described by Breitschwerdt et al. (1998). Moreover, another nested PCR assay was performed to amplify a fragment of the $16 \mathrm{~S}$ rRNA gene from Anaplasma platys (Kordick et al. 1999). The sequences of these primers are shown in Table 1 . These methods were used for the detection of E. canis or A. platys DNA in the 60 samples corresponding to Groups 1 and 2 and the Controls.
Statistical analysis. Statistical analysis was carried out using Epi Info 7.1.2.0 (Centers for Disease Control and Prevention, Atlanta, USA) and WinEpi (Facultad de Veterinaria, Universidad de Zaragoza, Spain). The concordance between the SPEED ${ }^{\circledR}$ EHRLI serological assay and the PCR was determined by calculating kappa values with $95 \%$ confidence intervals. According to the kappa values, the concordance between assays was classified as follows: 0-0.20 indicated poor agreement, 0.21-0.40 indicated fair agreement, 0.41-0.60 indicated moderate agreement, 0.61-0.80 indicated strong agreement, and 0.81-1 indicated almost perfect agreement (Landis \& Koch 1977).

\section{RESULTS}

The results of the SPEED ${ }^{\circledR}$ EHRLI serological assay versus the PCR-positive samples within each group and the agreement between both assays are summarized in Table 2 . The internal control used in the screening PCR assay was positive in all reactions.

The 20 healthy dog blood samples (Control Group) were negative both for the detection of antibodies by the SPEED ${ }^{\circledR}$ EHRLI serological assay and for the detection of DNA by the screening-PCR assay.

In Groups 1 and 2 (patients with presumptive diagnosis of CME in which the assay initially performed was the serology and the PCR assay was retrospectively performed), the concordance between the assays was poor (kappa value: 0.200, 95\%, CI -0.021-0.421). In Group 1, the nested PCR specific to Ehrlichia canis showed one positive result, whereas one of the samples was positive by the nested PCR specific to Anaplasma platys. Five out of the 20 dogs in Group 2 were PCR-positive to E. canis.

In Groups 3 and 4 (patients with presumptive diagnosis of CME in which the assay initially performed was the PCR assay and then the serological assay was retrospectively performed), the agreement between the assays was strong (kappa value: $0.650,95 \%$, CI 0.340-0.960).

Table 1. Primer pairs used in the present study to detect Ehrlichia canis and Anaplasma platys

\begin{tabular}{|c|c|c|c|}
\hline Primer pairs & Primer & Sequence $\left(5^{\prime} 3^{\prime}\right)$ & Reference \\
\hline \multirow[t]{2}{*}{ Family Anaplasmataceae } & EHR16S-D & GGTACCYACAGAAGAAGTCC & Parola et al. (2000) \\
\hline & EHR16S-R & TAGCACTCATCGTTTACAGC & \\
\hline \multirow{2}{*}{$\begin{array}{l}\text { Outside primers for family } \\
\text { Anaplasmataceae }\end{array}$} & EHR-OUT1 & CTGGCGGCAAGCYTAACACATGCCAACATCTCACGAC & Breitschwerdt et al. (1998) \\
\hline & EHR-OUT2 & GCTCGTTGCGGGACTTAACCCAACATCTCACGAC & \\
\hline \multirow[t]{2}{*}{ Inner primers for E. canis } & HE3-R & CTTCTATAGGTACCGTCATTATCTTCCСTAT & Breitschwerdt et al. (1998) \\
\hline & E. canis & CAATTATTTATAGCCTCTGGCTATAGGAA & \\
\hline \multirow[t]{2}{*}{ Inner primers for $A$. platys } & E. platys & GAT TTTTGTCGTAGCTTGCTA & Kordick et al. (1999) \\
\hline & Ehrl3-IP2 & TCATCTAATAGCGATAAATC & \\
\hline
\end{tabular}

Table 2. Results of serology and PCR assays

\begin{tabular}{|c|c|c|c|c|}
\hline Groups & No. of dogs & CI positive (\%) & PCR positive (\%) & Concordance (\%) \\
\hline Control & 20 & $0(0 \%)$ & $0(0 \%)$ & - \\
\hline 1 & 20 & $0(0)$ & $1(5 \%)$ & $0 / 1(0)$ \\
\hline 2 & 20 & $20(100 \%)$ & $5(25 \%)$ & $5 / 20(25)$ \\
\hline 3 & 20 & $4(20 \%)$ & $0(0 \%)$ & $0 / 4(0)$ \\
\hline 4 & 20 & $17(85 \%)$ & $20(100 \%)$ & $17 / 20(85)$ \\
\hline
\end{tabular}




\section{DISCUSSION}

In South America, the clinical suspicion of CME is increasingly common. However, there is no single method to reach definitive diagnosis of CME and several factors must be taken into account in the interpretation of the results (Waner et al. 2001, Otranto et al. 2009). The moment of sample collection, for example, as well as the sensitivity and diagnostic specificity of the assay used directly influence the final interpretation (Otranto et al. 2009, Harrus et al. 2012). Moreover, the presence of other tick-borne pathogens such as Hepatozoon spp. or Babesia spp. should be considered together with possible infection with Ehrlichia canis (Gal et al. 2007).

In our study, the concordance observed between the SPEED ${ }^{\circledR}$ EHRLI serological assay and the PCR assay used in the total dog population was moderate, in agreement with that reported by other authors (Maggi et al. 2014). All dogs included in the Control Group (exposed, without CME signs) were negative both by PCR and the SPEED ${ }^{\circledR}$ EHRLI serological assay. These findings coincide with previous reports from other authors in which no DNA of E. canis was detected in samples obtained from clinically healthy dogs (Cicuttin et al. 2015, Mascarelli et al. 2016). However, some studies carried out in Buenos Aires city have reported a prevalence value of 13.5 for Anaplasma platys (Cicuttin et al. 2011, 2014a). These differences in the prevalence of $A$. platys are probably due, among other factors, to the area from which the samples were obtained, the time of year in which the study was conducted, and the number of animals sampled. The absence of $E$. canis in dogs of the Control Group can be explained if we consider that only Rhipicephalus sanguineus of the temperate lineage has been detected in the area in which the sampling was carried out and as mentioned, the epidemiological and experimental studies relate $E$. canis with the tropical lineage and not with the temperate one (Moraes-Filho et al. 2015). The finding of animals with active infection (detected by PCR) raises the question of the mode of transmission in these cases. A possible explanation that could clarify this topic is that the dogs could have acquired the infection in other areas or that $R$. sanguineus of the temperate lineage would present low, but not null, vector capacity to transmit $E$. canis (Cicuttin et al. 2016).

With respect to the groups of patients in which the assay initially performed was the serology and the PCR assay was retrospectively performed (Groups 1 and 2), we observed poor concordance between the assays evaluated. The finding of a positive dog by PCR and negative by the SPEED ${ }^{\circledR}$ EHRLI serological assay could reflect the onset of the disease with presence of bacteremia and absence of detectable antibodies (Iqbal et al. 1994). It should be noted that the use of PCR for screening (combined with the specific nested PCR) in this group of samples also allowed detecting infection with A. platys in a patient in whom the serology had been negative. On the other hand, only five dogs of Group 3 were also positive by PCR, which may be due to several factors. First, the SPEED ${ }^{\circledR}$ EHRLI serological assay may give false positive results in animals that maintain detectable antibody titers subsequent to recovery from infection or that have been exposed to the agent (Iqbal et al. 1994, Wen et al. 1997, Harrus et al. 1998, Cetinkaya et al. 2016). It should also be considered that there are cross reactions between E. canis and other strains of Ehrlichia (which circulate in ticks of our country), as well as between E. canis and A. platys, although to a lesser extent (Dumler et al. 2001, Harrus et al. 2012).
Secondly, the analysis of samples from patients who had received treatment with antibiotics (which is not discriminated in the protocol for sending samples to our lab) decreases or eliminates the number of circulating microorganisms in the blood, causing false negative results by the PCR assay. Likewise, some authors have mentioned that the persistence of $E$. canis in bone marrow or spleen (chronic phase of CME) with low levels of microorganisms in peripheral blood could result in DNA concentrations below the limit of detection of the PCR (Otranto et al. 2010, Harrus et al. 2012). Finally, the presence of inhibitors of the enzyme polymerase in whole blood samples can affect the amplification and efficiency of the PCR assay, causing false negative results (Harrus \& Waner 2011). In our study, an endogenous amplification control, which allowed us to monitor if the reaction was inhibited, was included in each PCR reaction.

Groups 3 and 4, in which the assay initially performed was the PCR and the serological assay was retrospectively performed, showed a strong concordance between both assays. Samples negative for PCR but positive for the SPEED ${ }^{\circledR}$ EHRLI serological assay obtained in Group 4 may be due to the mentioned factors, whereas samples positive for PCR and negative for SPEED ${ }^{\circledR}$ EHRLI may have been extracted in the acute stage of the disease before the immune system developed a detectable antibody response (Harrus et al. 1998). In this context, when rapid qualitative serological assays are used, it is important to consider the cut-off point defined by the manufacturer. For example, the Snap 4D plus kit (IDEXX) was standardized for the detection of an antibody titer above $1 / 160$. Therefore, any sample that shows antibody levels below that value will give a negative result (Harrus et al. 2012). The cut-off value for the SPEED ${ }^{\circledR}$ EHRLI serological assay is not specified; however, it is possible that it is in a similar range. According to previous studies, the methods based on ELISA or immunochromatography are able to differentiate seronegative and seropositive animals when the antibody titer is $\geq 1 / 320$, while lower titers could cause false negative results (Waner et al. 2000).

\section{CONCLUSIONS}

The results of our study suggest that the combination of molecular and serological methods increases certainty in the diagnosis of CME. However, it is important to note that serological diagnosis is not conclusive in an endemic area for CME because these assays do not differentiate between infection and exposure to the microorganism. Therefore, the use of rapid serological assays as initial screening together with the subsequent confirmation by PCR seem to be useful diagnostic tools in the confirmation of EMC in dogs.

Moreover, to suitable diagnosis of EMC clinicians should take into account epidemiological data, clinical signs, laboratory test results and possible co-infections with other tick-borne pathogens transmitted by Rhipicephalus sanguineus ticks.

Acknowledgements.- We thank Dr. Fontana Lorena from the "Laboratorio Veterinario Diagnóstico Sur" and colleagues at "Instituto de Zoonosis Luis Pasteur and Hospital Escuela (Facultad de Ciencias Veterinarias) Universidad Nacional de La Plata" for submitted samples.

Conflict of interest statement.- The authors have no competing interests. 


\section{REFERENCES}

Baneth G., Harrus S., Ohnona F.S. \& Schlesinger Y. 2009. Longitudinal quantification of Ehrlichia canis in experimental infection with comparison to natural infection. Vet. Microbiol. 136(3/4):321-325. <http://dx.doi. org/10.1016/j.vetmic.2008.11.022 > <Mid:19128893>

Breitschwerdt E.B., Hegarty B.C., Hancock S.I. \& Carolina N. 1998. Sequential evaluation of dogs naturally infected with Ehrlichia canis, Ehrlichia chaffeensis, Ehrlichia equi, Ehrlichia ewingii, or Bartonella vinsonii. J. Clin. Microbiol. 36(9):2645-2651. <PMid:9705408>

Bremer W.G., Schaefer J.J., Wagner E.R., Ewing S.A., Rikihisa Y., Needham G.R., Jittapalapong S., Moore D.L. \& Stich R.W. 2005. Transstadial and intrastadial experimental transmission of Ehrlichia canis by male Rhipicephalus sanguineus. Vet. Parasitol. 131(1/2):95-105. <http://dx.doi.org/10.1016/j. vetpar.2005.04.030><PMid:15941624>

Çetinkaya H., Matur E., Akyazi İ., Ekiz E.E., Aydin L. \& Toparlak M. 2016. Serological and molecular investigation of Ehrlichia spp. and Anaplasma spp. in ticks and blood of dogs, in the Thrace Region of Turkey. Ticks Tick Borne Dis. 7(5):706-714. <http://dx.doi.org/10.1016/j.ttbdis.2016.02.021> $<$ PMid:26961274>

Cicuttin G.L., Navarro O., Connor M., Lobo B. \& Jado I. 2011. Evidencia molecular de Anaplasma platys en caninos domésticos de la Ciudad Autónoma de Buenos Aires. Revta FAVE Ciênc. Vet. 10(2):19-23.

Cicuttin G.L., Brambati D.F., Rodríguez Eugui J.I., Lebrero C.G., Salvo M.N., Beltrán F.J., Gury Dohmen F.E., Jado I. \& Anda P. 2014a. Molecular characterization of Rickettsia massiliae and Anaplasma platys infecting Rhipicephalus sanguineus ticks and domestic dogs, Buenos Aires (Argentina). Ticks Tick Borne Dis. 5(5):484-488. <http://dx.doi.org/10.1016/j.ttbdis.2014.03.001> $<$ PMid:24907186>

Cicuttin G.L., Vidal P., Nazarena De Salvo M., Beltrán F.J. \& Gury Dohmen F.E. 2014b. Detección molecular de Rickettsia massiliae y Anaplasma platys en garrapatas Rhipicephalus sanguineus y caninos domésticos del municipio de Bahía Blanca (Argentina). Revta Chil. Infectol. 31(5):563-568. <http:// dx.doi.org/10.4067/S0716-10182014000500008> <PMid:25491455>

Cicuttin G.L., Tarragona E.L., De Salvo M.N., Mangold A.J. \& Nava S. 2015. Infection with Ehrlichia canis and Anaplasma platys (Rickettsiales: Anaplasmataceae) in two lineages of Rhipicephalus sanguineus sensu lato (Acari: Ixodidae) from Argentina. Ticks Tick Borne Dis. 6(6):724-729. <http://dx.doi.org/10.1016/j.ttbdis.2015.06.006> <PMid:26100492>

Cicuttin G.L., De Salvo M.N. \& Gury Dohmen F.E. 2016. Molecular characterization of Ehrlichia canis infecting dogs, Buenos Aires. Ticks Tick Borne Dis. 7(5):954957.<http://dx.doi.org/10.1016/j.ttbdis.2016.04.017><PMid:27236582>

Cicuttin G.L., De Salvo M.N. \& Nava S. 2017a. Two novel Ehrlichia strains detected in Amblyomma tigrinum ticks associated to dogs in peri-urban areas of Argentina. Comp. Immunol. Microbiol. Infect. Dis. 53:40-44. <http://dx.doi.org/10.1016/j.cimid.2017.07.001> <PMid:28750866>.

Cicuttin G.L., De Salvo M.N., Silva D.A., Brito M. \& Nava S. 2017b. Ehrlichia canis (Rickettsiales: Anaplasmataceae) en garrapatas Rhipicephalus sanguineus sensu lato del linaje templado (Acari: Ixodidae), provincia de Buenos Aires, Argentina. Revta FAVE. Ciênc. Vet. 16:93-96.

Dumler J.S., Barbet A.F., Bekker C.P.J., Dasch G.A., Palmer G.H., Ray S.C., Rikihisa Y. \& Rurangirwa F.R. 2001. Reorganization of genera in the families Rickettsiaceae and Anaplasmataceae in the order Rickettsiales: unification of some species of Ehrlichia with Anaplasma, Cowdria with Ehrlichia and Ehrlichia with Neorickettsia, description of six new species conmbinations and designation of Ehrlichia equi and "HE agent" as subjective synonyms of Ehrlichia phagocytophila. Int. J. Syst. Evol. Microbiol. 51(6):2145-2165. <http://dx.doi.org/10.1099/00207713-51-6-2145><PMid:11760958>

Eiras D.F., Craviotto M.B., Vezzani D., Eyal O. \& Baneth G. 2013. First description of natural Ehrlichia canis and Anaplasma platys infections in dogs from Argentina. Comp. Immunol. Microbiol. Infect. Dis. 36(2):169-173. <http:// dx.doi.org/10.1016/j.cimid.2012.11.008><PMid:23273677>
Gal A., Harrus S., Arcoh I., Lavy E., Aizenberg I., Mekuzas-Yisaschar Y. \& Baneth G. 2007. Coinfection with multiple tick-borne and intestinal parasites in a 6-week-old dog. Can. Vet. J. 48(6):619-622. <PMid:17616060>

Harrus S. \& Waner T. 2011. Diagnosis of canine monocytotropic ehrlichiosis (Ehrlichia canis): an overview. Vet. J. 187(3):292-296. <http://dx.doi. org/10.1016/j.tvjl.2010.02.001><PMid:20226700>

Harrus S., Waner T. \& Neer T.M. 2012. Ehrlichia canis infection, p.227-238. In: Greene C.E. (Ed.), Infectious Diseases of the Dog and Cat. Elsevier, Missouri.

Harrus S., Waner T., Aizenberg J., Foley J., Poland A. \& Bark H. 1998. Amplification of ehrlichal DNA from dogs 34 months after infection with Ehrlicia canis. J. Clin. Microbiol. 36(1):73-76. <PMid:9431923>

Harrus S., Alleman A.R., Bark H., Mahan S.M. \& Waner T. 2002. Comparison of three enzyme-linked immunosorbant assays with the indirect immunofluorescent antibody test for the diagnosis of canine infection with Ehrlichia canis. Vet. Microbiol. 86(4):361-368. <http://dx.doi.org/10.1016/ S0378-1135(02)00022-6><PMid:11955786>

Iqbal Z., Chaichanasiriwithaya W. \& Rikihisa Y. 1994. Comparison of PCR with other tests for early diagnosis of canine ehrlichiosis. J. Clin. Microbiol. 32(7):1658-1662. <PMid:7929754>

Klag A.R., Dunbar L.E. \& Girard C.A. 1991. Concurrent ehrlichiosis and babesiosis in a dog. Can. Vet. J. 32(5):305-307. <PMid:17423787>

Kordick S.K., Breitschwerdt E.B., Hegarty B.C., Southwick K.L., Colitz C.M., Hancock S.I., Bradley J.M., Rumbough R., Mcpherson J.T. \& MacCormack J.N. 1999. Coinfection with multiple tick-borne pathogens in a Walker Hound kennel in North Carolina. J. Clin. Microbiol. 37(8):2631-2638. $<$ PMid:10405413>

Labruna M.B., McBride J.W., Camargo L.M., Aguiar D.M., Yabsley M.J., Davidson W.R., Stromdahl E.Y., Williamson P.C., Stich R.W., Long S.W., Camargo E.P. \& Walker D.H. 2007. A preliminary investigation of Ehrlichia species in ticks, humans, dogs, and capybaras from Brazil. Vet. Parasitol. 143(2):189-195. <http://dx.doi.org/10.1016/j.vetpar.2006.08.005> <PMid:16962245>

Landis J.R. \& Koch G.G. 1977. The measurement of observer agreement for categorical data. Biometrics 33(1):159-174. <http://dx.doi. org $/ 10.2307 / 2529310><$ PMid:843571>

Leiva M., Naranjo C. \& Peña M.T. 2005. Ocular signs of canine monocytic ehrlichiosis: a retrospective study in dogs from Barcelona, Spain. Vet. Ophthalmol. 8(6):387-393. <http://dx.doi.org/10.1111/j.1463-5224.2005.00409.x> $<$ PMid:16359361>

Maggi R.G., Birkenheuer A.J., Hegarty B.C., Bradley J.M., Levy M.G. \& Breitschwerdt E. 2014. Comparison of serological and molecular panels for diagnosis of vector-borne diseases in dogs. Parasit. Vectors 7(1):127. <http://dx.doi. org/10.1186/1756-3305-7-127><PMid:24670154>

Martin C. 2004. Les Ehrlichioses du chien, étude bibliographique, diagnostic et comparaison de trois kits de diagnostic serologique rapide de l'ehrlichiose monocytaire. Doctoral Dissertation, Université Claude-Bernard, Lyon.

Mascarelli P.E., Tartara G.P., Pereyra N.B. \& Maggi R.G. 2016. Detection of Mycoplasma haemocanis, Mycoplasma haematoparvum, Mycoplasma suis and other vector-borne pathogens in dogs from Córdoba and Santa Fe, Argentina. Parasit. Vectors. 9(1):642. <http://dx.doi.org/10.1186/ s13071-016-1920-8><PMid:27978844>

Mera y Sierra R. \& Neira G. 2014. Ocurrencia de Ehrlichia canis en caninos de la provincia de Mendoza. III Congreso Panamericano de Zoonosis and VIII Congreso Argentino de Zoonosis, La Plata, Argentina.

Moraes-Filho J., Krawczak F.S., Costa F.B., Soares J.F. \& Labruna M.B. 2015 Comparative evaluation of the vector competence of four south American populations of the Rhipicephalus sanguineus group for the bacterium Ehrlichia canis, the agent of canine monocytic ehrlichiosis. PLoS One 10(9):e0139386. <http://dx.doi.org/10.1371/journal.pone.0139386> <PMid:26414283>

Mylonakis M.E., Koutinas A.F., Billinis C., Leontides L.S., Kontos V., Papadopoulos O., Rallis T. \& Fytianou A. 2003. Evaluation of cytology in the diagnosis 
of acute canine monocytic ehrlichiosis (Ehrlichia canis): a comparison between five methods. Vet. Microbiol. 91(2/3):197-204. <http://dx.doi. org/10.1016/S0378-1135(02)00298-5><PMid:12458168>

Neer T.M., Breitschwerdt E.B., Greene R.T. \& Lappin M.R. 2002. Consensus statement on ehrlichial disease of small animals from the infectious disease study group of the American College of Veterinary Internal Medicine. J. Vet. Intern. Med. 16:309-315. <PMid:12041661>

Otranto D., Dantas Torres F. \& Breitschwerdt E. 2009. Managing canine vectorborne diseases of zoonotic concern: part one. Trends Parasitol. 25(4):157163. <http://dx.doi.org/10.1016/j.pt.2009.01.003><PMid:19269898>

Otranto D., Testini G., Dantas-Torres F., Latrofa M.S., Diniz P.P., Caprariis D., Lia R.P., Mencke N., Stanneck D., Capelli G. \& Breitschwerdt E.B. 2010. Diagnosis of canine vector-borne diseases in young dogs: a longitudinal study. J. Clin. Microbiol. 48(9):3316-3324. <http://dx.doi.org/10.1128/ JCM.00379-10><PMid:20660218>

Parola P., Roux V., Camicas J.L., Baradji I., Brouqui P. \& Raoult D. 2000. Detection of ehrlichiae in African ticks by polymerase chain reaction. Trans. R. Soc. Trop. Med. Hyg. 94(6):707-709. <http://dx.doi.org/10.1016/S00359203(00)90243-8> <PMid:11198664>

Ramos C.A.N., Ramos R.A.N., Araújo F.R., Guedes Junior D.S., Souza I.I.F., Ono T.M., Vieira A.S., Pimentel D.S., Rosas E.O., Faustino M.A.G. \& Alves L.C. 2009. Comparação de nested-PCR com o diagnóstico direto na detecção de Ehrlichia canis e Anaplasma platys em cães. Revta Bras. Parasitol. Vet. 18(Suppl.1):58-62. <http://dx.doi.org/10.4322/rbpv.018e1011> $<$ PMid:20040193>
Rotondano T.E., Almeida H.K., Krawczak F.S., Santana V.L., Vidal I.F., Labruna M.B., Azevedo S.S., Adelmeida A.M. \& Melo M.A. 2015. Survey of Ehrlichia canis, Babesia spp. and Hepatozoon spp. in dogs from a semiarid region of Brazil. Revta Bras. Parasitol. Vet. 24(1):52-58. <http://dx.doi.org/10.1590/ S1984-29612015011><PMid:25909253>

Stich R.W., Rikihisa Y., Ewing S.A., Needham G.R., Grover D.L. \& Jittapalapong S. 2002. Detection of Ehrlichia canis in canine carrier blood and in individual experimentally infected ticks with a p30-based PCR assay. J. Clin. Microbiol. 40(2):540-546. <http://dx.doi.org/10.1128/JCM.40.2.540-546.2002> $<$ PMid:11825969>

Unver A., Rikihisa Y., Karaman M. \& Ozen H. 2009. An acute severe ehrlichiosis in a dog experimentally infected with a new virulent strain of Ehrlichia canis. Clin. Microbiol. Infect. 15(Suppl.2):59-61. <http://dx.doi. org/10.1111/j.1469-0691.2008.02634.x><PMid:19548986>

Waner T., Strenger C. \& Keysary A. 2000. Comparison of a clinic-based ELISA test kit with the immunofluorescence test for the assay of Ehrlichia canis antibodies in dogs. J. Vet. Diagn. Invest. 12(3):240-244. <http://dx.doi. org/10.1177/104063870001200307> <PMid:10826837>

Waner T., Harrus S., Jongejan F., Bark H., Keysary A. \& Cornelissen A.W. 2001. Significance of serological testing for ehrlichial diseases in dogs with special emphasis on the diagnosis of canine monocytic ehrlichiosis caused by Ehrlichia canis. Vet. Parasitol. 95(1):1-15. <http://dx.doi.org/10.1016/ S0304-4017(00)00407-6><PMid:11163693>

Wen B., Rikihisa Y., Mott J.M., Greene R., Kim H.Y., Zhi N., Couto G.C., Unver A. \& Bartsch R. 1997. Comparison of nested PCR with immunofluorescentantibody assay for detection of Ehrlichia canis infection in dogs treated with doxycycline. J. Clin. Microbiol. 35(7):1852-1855. <PMid:9196207> 